\title{
Borders ANd Business CyCles
}

\author{
Todd E. Clark \\ Eric van Wincoop \\ SePtember 1999 \\ RWP 99-07
}

\author{
Research Division \\ Federal Reserve Bank of Kansas City
}

Todd E. Clark is an assistant vice president and economist at the Federal Reserve Bank of Kansas City. Eric van Wincoop is a senior economist at the Federal Reserve Bank of New York. The authors would like to thank participants at the conference "Lessons from Intranational Economics for International Economics" at Studienzentrum Gerzensee, Switzerland, and the Latin American Meeting of the Econometric Society in Cancun,

Mexico. They would also like to thank Marco del Negro, John Helliwell, Antonio Fatas, and Lucrezia Reichlin for discussions and comments.

They thank Bent Sorensen and Antonio Fatas for making available data collected in their own research. The authors are also very much indebted to Scott Nicholson for excellent research support and collecting the data. The views expressed in the paper are those of the authors and do not necessarily reflect the position of the Federal Reserve Bank of New York, the Federal Reserve Bank of Kansas City, or the Federal Reserve System.

Clark e-mail: todd.e.clark@kc.frb.org

Van Wincoop e-mail: eric.vanwincoop@ny.frb.org 


\begin{abstract}
We document that business cycles of U.S. Census regions are substantially more synchronized than those of European Union countries, both over the past four decades and the past two decades. Data from regions within the four largest European countries confirm the presence of a European border effect -within-country correlations are substantially larger than cross-country correlations. These results continue to hold after controlling for exogenous factors such as distance and size. We consider the role of four factors that have received a lot of attention in the debate about EMU: sectoral specialization, the level of trade, monetary policy and fiscal policy. We find that the lower level of trade between European countries, and to a lesser extent the higher degree of sectoral specialization, can explain most of the observed border effect.
\end{abstract}




\section{Introduction}

National borders have economic relevance to the extent that economic policies and institutions differ across those borders and discriminate between residents on different sides of the border. In Europe countries are gradually becoming more integrated as barriers to cross-border flows of goods, capital and labor are being removed and monetary and fiscal policies are becoming more coordinated. Particularly, the adoption of a single currency has led to significant debate about where this process might lead. In this context valuable lessons can be learned from intranational macroeconomics, the study of regions that are located in the same country and therefore not separated by national borders. In this paper we will consider what lessons may be drawn from regions within the United States about the synchronization of business cycles across European countries.

More specifically, we address the following four questions. First, using simple correlations of output or employment to measure business cycle synchronization, what is the evidence on the extent of synchronization among European countries in comparison to regions within the United States? Second, to what extent can we attribute those differences to European national borders? Third, has the role of the border diminished over time? And finally, what accounts for the border effect?

In addressing these questions we will consider evidence from 14 European Union countries and 9 U.S. Census regions. We need to be careful, however, in drawing conclusions about the importance of European national borders from a direct comparison of U.S. and European business cycle synchronization. First, European countries and U.S. regions differ not only in that the former are separated by national borders, but also in that European policies overall differ from those in the United States. In particular, in almost all European countries labor market policies are more rigid than those in the United States. In order to focus exclusively on the role of European borders we will therefore also consider a dataset based on regions within the four largest European countries. By comparing within-country to cross-country correlations for those regions we can identify the role played by borders between those countries.

A second potential problem in identifying the role of borders is that differences between within-country and cross-country correlations can also be related to exogenous factors, such as distance and size, that are unrelated to national borders. Distance is an important barrier, raising the cost of transportation and communication, but is not specifically related to the border. Size is also relevant as larger regions tend to have more diversified production structures. We will follow an approach similar to that used 
in the literatures that have compared within-country to cross-country levels of trade and relative price volatility. ${ }^{1}$ In the same spirit as those literatures, we will control for exogenous factors by regressing business cycle correlations on a common border dummy and measures of distance, adjacency and size.

In accounting for European national border effects, we will identify the role of four factors: sectoral specialization, trade, monetary policy and fiscal policy. As a result of trade and industrial policy the extent of industrial specialization and the level of trade may be higher within a country than across countries. By identifying the role of monetary and fiscal policies important lessons may be learned about the implications of European Monetary Union for future European business cycle synchronization. We evaluate the importance of these factors by including in the regression measures of production structure similarity, trade, and similarity of fiscal and monetary policies.

Our analysis extends and complements two previous literatures. The first directly compares within-country to cross-country correlations. Bayoumi and Eichengreen (1993, 1996) and Wynne and Koo (1997) compare correlations across regions in the U.S. to countries in Europe. Using data for regions in European nations, Fatás (1997) compares correlations between regional and national growth rates to correlations between regional and Europe-wide growth rates. The second literature, surveyed by Clark and Shin (1999), decomposes the sources of variation into international, nation-specific, regionspecific, and industry-specific components. The findings of both of these literatures generally suggest that European business cycles are less synchronized than those of U.S. regions. Our approach has two advantages over these previous literatures. First, by explicitly controlling for exogenous factors that are unrelated to national borders (distance and size) we are able to more accurately measure the role of the border in affecting business cycle comovement. Second, our approach naturally lends itself to identifying the source of the border effect.

The remainder of the paper is organized as follows. In section 2 we discuss the general methodology and econometric issues. Section 3 describes the data and reports results on the role of the border and on how much the border effect has changed over time. We also compare our results to related evidence in the literature. Section 4 explores what accounts for the border effect, focusing on the role of sectoral specialization, trade, monetary and fiscal policies. The final section concludes.

\footnotetext{
${ }^{1}$ For the trade literature see McCallum (1995), Helliwell (1997,1998), Wei (1996), and Wolf (1999). For the relative price literature see Engel and Rogers $(1996,1999)$.
} 


\section{Econometric Methodology}

We begin by directly comparing within-country to cross-country business cycle correlations. Let $\rho$ denote the vector of unique population correlations of interest, $\hat{\rho}$ the vector of estimated correlations and $v$ the sampling error for the estimated vector:

$$
\hat{\rho}=\rho+v
$$

We estimate the variance of the estimated correlation vector, which is the same as the variance of the sampling error, using the standard GMM methods described in Ogaki (1993). This variance estimator is denoted by $\frac{1}{T} \hat{\Sigma}_{v}$, where $\hat{\Sigma}_{v}$ is the estimate of the asymptotic variance-covariance matrix and $T$ is the number of time-series observations used to estimate the correlations. ${ }^{2}$ Since the average within-country correlations, average cross-country correlations, and their difference (the border effect) are all just linear combinations of the sample correlations, taking the form $\delta^{\prime} \hat{\rho}$, their variance is easily computed as $\operatorname{var}\left(\delta^{\prime} \hat{\rho}\right)=\delta^{\prime}\left(\frac{1}{T} \hat{\Sigma}_{v}\right) \delta$.

We proceed to estimate a cross-section regression of the estimated correlations on a set of explanatory variables. Formally, we estimate by OLS the equation

$$
\hat{\rho}_{i}=x_{i}^{\prime} \beta+e_{i}
$$

In our baseline specification, the variables in $x_{i}$ include a constant, a border dummy that is 1 when regions are located in the same country, the log of distance, and a populationbased measure of the size of two regions. In further investigating what might explain any border effects, the set of explanatory variables is expanded to include measures of production structure similarity, trade, and monetary and fiscal policy similarity.

In estimating standard errors for the parameters of (2), we depart from the practice of estimating the variance-covariance matrix of $\hat{\beta}$ using just the standard White (1980) correction for heteroskedasticity, as in Frankel and Rose (1998) and Imbs (1998a). Frankel and Rose argue that the resulting estimator takes appropriate account of the sampling uncertainty in the estimated correlation $\hat{\rho}_{i}$. But, if the sampling error in one correlation $\hat{\rho}_{i}$ is correlated with the sampling error in another correlation $\hat{\rho}_{j}$, there will be dependencies across the residuals of (2) that the White correction fails to adjust for. Such dependencies are likely to be important, and ignoring them will lead to understated standard errors. Indeed, in our analysis, White-adjusted standard errors based on the

\footnotetext{
${ }^{2}$ Our variance estimator incorporates the Newey and West (1987) correction for serial correlation, using 2 lags for annual data.
} 
simple cross-section regression are generally lower, often much lower, than those we report.

We base our estimate of the variance-covariance matrix of $\hat{\beta}$ on the time-series sampling error in the estimated correlations. Although we treat the sample correlation $\hat{\rho}_{i}$ as stochastic (due to sampling error), we assume that the population coefficient $\rho_{i}$ is not a random variable. We suppose that the population correlation $\rho_{i}$ is a deterministic function of a wide range of variables, of which we only observe a subset. Formally, we may write $\rho=X \beta+Z \gamma$, where $Z$ is orthogonal to $X$. $\beta$ measures both the direct effect on the correlation, and the indirect effect through variables with which it is correlated. ${ }^{3}$ Substituting (1) yields

$$
\hat{\rho}=X \beta+Z \gamma+v .
$$

OLS yields an unbiased estimate of $\beta$. Using the time-series estimate $\hat{\Sigma}_{v}$, the estimated variance-covariance matrix of $\hat{\beta}$ is

$$
\operatorname{var}(\hat{\beta})=\left(X^{\prime} X\right)^{-1} X^{\prime}\left(\frac{1}{T} \hat{\Sigma}_{v}\right) X\left(X^{\prime} X\right)^{-1}
$$

While the assumption that $\rho_{i}$ is deterministic may seem strong, our method produces standard error estimates that are clearly the "right" ones in the simple case where we only regress the correlation on a border dummy and a constant. The standard error associated with the border dummy coefficient computed using (4) is the same as that corresponding to the difference between average within-country and cross-country correlations discussed above. In the more complicated case where other regressors are included, our standard error estimates are computed in a way that is methodologically consistent with the simple approach.

In the results reported below, we use both full time series of the data and sub-samples of the data. In computing variance estimates for the sub-samples, we use an estimate of the asymptotic variance matrix that is based on the full-sample of data, rather than the sub-samples. We use the same $\hat{\Sigma}_{v}$ estimate of the asymptotic variance-covariance matrix in the full-sample and sub-sample analyses for a given set of regions. To obtain an appropriate estimate of the sample variance of the correlations estimated with a given $T^{\prime}$ observations, we just normalize $\hat{\Sigma}_{v}$ by $T^{\prime}$. Our rationale for basing inference on the full-sample estimate of the asymptotic covariance matrix is that small samples will give highly imprecise variance estimates. The GMM-based variance estimate uses the

\footnotetext{
${ }^{3}$ For example, distance may only affect the correlation indirectly through its effect on trade. Similarly, size may only affect the correlation indirectly though its effect on diversification.
} 
fourth moments of the data, which, as noted by Davidson and MacKinnon (1983), will be inefficient estimates of the population moments. Burnside and Eichenbaum (1996) and Christiano and den Haan (1996) show that hypotheses tests involving correlations have poor small-sample properties.

We will also estimate (2) jointly for two sub-samples. In that case we compute the variance of $v$ for each of the sub-samples as discussed above, while we assume that the sampling error is uncorrelated across the sub-samples.

\section{Evidence on the Role of the Border}

In this section we first discuss the datasets. After that we describe the evidence on the role of national borders, and on the change in the role of national borders over time. At the end of the section we compare our results to related evidence in the literature.

\subsection{Data}

We apply the methodology described above to three basic combinations of regions: (1) 9 U.S. Census regions and 14 EU countries; (2) 8 regions in France and 8 regions in Germany; and (3) a total of 38 regions in France, Germany, Italy, and the United Kingdom. Because U.S. states are generally much smaller than European nations, the states are aggregated to the 9 Census regions for the purpose of comparing within-U.S. correlations to correlations across EU countries, although we more formally control for size in the regressions. The set of European regions in (2) and (3) is the same as in Fatás (1997). Although we present some basic border effect estimates for the broader European region dataset (3), we generally focus on results for the narrower dataset (2) because it is hard to control for distance. Distances between U.K. regions and regions of other countries, and between Italian regions and those of other countries, are generally much larger than within-country distances, so the distance variable starts to act as a border dummy. For France and Germany there is substantial overlap between within-country and cross-country distances.

For each combination of regions we use data on both employment and GDP. Because the availability of quarterly data is limited, we use just annual figures. For the U.S.-EU dataset the sample period (of the raw data) is 1961-1997 for employment and 1963-1996 for GDP. The European regional datasets are shorter: 1970-1992 for employment and 1982-1996 for GDP. To isolate fluctuations at business cycle frequencies, the data are 
transformed by two different methods: (1) taking simple percent changes; and (2) passing the data through the Hodrick and Prescott (1997) filter. ${ }^{4}$ In applying the HodrickPrescott (HP) filter, we set the filter's smoothing parameter $\lambda$ at 10 . While many studies of annual data, such as Backus and Kehoe (1992), set $\lambda$ at 100, Baxter and King (1995) suggest a value of 10 is more appropriate. ${ }^{5}$

As detailed in the appendix, we use simple measures of distance and size. For the U.S. Census regions distance is measured as the log of the population-weighted average of distances between the states within each Census region. The distances between states are defined as geographic distances - that is, taking the earth's curvature into account between capital cities. Similarly, distances between the French and German regions and between the EU-14 countries are population-weighted averages of geographic distances between very small NUTS-3 regions. Size is defined as the sum of the log populations of two regions, measured in a single year.

\subsection{Evidence Based on the Entire Sample}

Table 1 reports some basic correlation results for our three datasets. It reports average within-country and cross-country correlations, as well the difference (border dummy). Standard errors are in parentheses.

For all three datasets the average within-country correlation is larger than the crosscountry correlation, and this difference is statistically significant. The average correlation of annual employment growth across the 9 U.S. Census regions is 0.52 higher than the average correlation across the 14 EU countries. The difference is 0.37 for GDP growth rates. Numbers are similar for HP-filtered data. This difference in correlations is strongly significant, suggesting that business cycles of the EU countries would become substantially more synchronized if European countries became as integrated as U.S. regions.

Similarly large border effects based on regions within European countries confirm that it is primarily national European borders driving the results for the U.S.-EU comparison. On average the correlation of annual employment growth rates between a region in France and a region in Germany is 0.42 lower than between regions located in the same country. The national border between Germany and France appears to play an

\footnotetext{
${ }^{4}$ In the interest of brevity, we omit results based on the Baxter and King (1995) filter because they are very similar to those for percent changes and HP-filtered data.

${ }^{5}$ We find that, in some cases, data filtered with $\lambda=100$ produces counterintuitive results.
} 
important role. This result is again strongly significant, and is also confirmed by the other business cycle measures. Using the broader set that includes regions in Italy and the U.K. as well as in France and Germany, it remains the case that business cycle correlations are higher within countries than across countries, with an implied border effect that is comparable to the estimates for just France and Germany.

As stressed in the introduction, correlations alone cannot definitively tell us how much business cycle correlations across countries would change if borders were eliminated. To assure that national borders matter we need to control for "exogenous" factors that are unrelated to the presence of borders. A lower correlation among regions of the same country can simply be the result of lower average distance than between regions of different countries. Similarly, it is possible that the correlations between the 9 Census regions is higher than between European countries because of somewhat larger size. Although adjacency may also matter for business cycle correlations, we find that adding a dummy for adjacency does not alter the basic results described below and therefore omit these results.

Table 2 reports the result of regressions of the business cycle correlation on a common border dummy, the log of distance, and size. Although the coefficients on distance and size have the expected sign and are generally statistically significant, comparing Tables 1 and 2 shows that controlling for distance and size has little effect on the estimated importance of the border. In the U.S.-EU dataset, for three of the four business cycle measures the common border coefficient in Table 2 is exactly the same as the difference in average correlations in Table 1. The average distance between the U.S. regions (1938 miles) is larger than between the EU countries (1421 miles), while the average size of the U.S. regions (27.6 million people in 1990) is somewhat larger than that of the European countries (24.9 million people in 1994). The larger distance lowers the correlation across the U.S. regions relative to the EU countries by about the same amount as the larger size raises it. Simultaneously controlling for distance and size therefore does not change the estimated border effect. Similarly, the estimated border effect for regions in France and Germany is little changed when distance and size are taken into account.

\subsection{Changes Across Sub-Samples}

So far we have established a strong role of national European borders in the synchronization of business cycles across regions. We will now examine whether the significance of national borders has changed over time. For the U.S.-EU and France-Germany datasets 
we break the sample into two periods of equal length. It may be desirable to make the periods even shorter, for example 5-year intervals, but the standard errors associated with average correlations based on such short periods are much too large to allow for meaningful analysis.

Table 3 reports the same results as Table 2, but estimated jointly for the first and second halves of the sample. It shows how the border effect has changed from the first to the second half of the sample, after controlling for distance and size. Table 4 reports the raw correlations for both subsamples, providing insight on the change in both within-country and cross-country correlations. Finally, Figures 1 and 2 show the crosscountry correlations (squares) and within-country correlations (diamonds) as a function of distance, comparing for each dataset the first half to the second half of the sample.

Table 3 shows that the importance of the border has declined for the U.S.-EU dataset. For both employment and GDP growth rates the border effect drops by about 0.2 from the first to the second half of the sample, lowering the border effect to 0.39 for employment growth rates and 0.20 for GDP growth rates. For European regions the drop in the border effect is very small and insignificant. The border effect during the second half of the sample is 0.34 for employment growth rates. We have to be careful interpreting these results. A drop in the border effect does not necessarily imply that European countries have become more integrated. The change in the border effect can also be a result of changes in the extent of integration among regions of the same country. It is therefore of interest to know to what extent the change in the border effect is associated with a change in within-country correlations or a change in the cross-country correlations.

Table 4 shows that, for the U.S.-EU dataset, almost all of the drop in the border effect is due to a lower average correlation across U.S. regions. Table 4 shows that the average correlation across European countries remains practically unchanged from the first to the second half of the sample, while for U.S. regions both the employment and output growth correlations fell by 0.2 . If the drop in the common border coefficient were the result of increased integration across European countries we would have expected the exact opposite: a rise in the average correlation across European countries towards a level seen across U.S. regions.

The drop in the correlation across the U.S. regions is statistically significant, so we cannot simply attribute it to a sample-specific change in the importance of common shocks. Correlations across U.S. states have declined much less - the average employment correlation fell by a statistically insignificant 0.06 from the first to the second half of the sample. When we estimate the border effect based on state data and EU country 
data jointly, controlling for distance and size, we find that the border effect fell from 0.62 to 0.53 . The 0.09 decline has a standard error of 0.13 and is therefore insignificant. These results are plausible if, during the second half of the sample, shocks affecting a state tended to be shared more by other states in the region, leading to larger regional shocks. An example is the negative oil shock in the 1980s, which affected three of the states in the West South Central region: Texas, Louisiana and Oklahoma. Figure 1 shows that seven of the correlations between U.S. Census regions drop to zero in the second half of the sample. All of those involve the West South Central region.

In the case of the France-Germany regional dataset, neither within-country nor cross-country correlations have changed much. Consistent with the results of Fatás (1997), the average within-country correlation has declined, but not by a statistically significant amount. The average cross-country correlation has not changed if growth rates are used and declined slightly if $\mathrm{HP}$-filtered data are used. Figure 2 confirms that there is no evidence of a change in the border effect for regions in France and Germany. For a given distance, the correlations remain substantially lower between French and German regions (squares) than between regions of the same country (diamonds).

\subsection{Literature Comparison}

Our results are generally in line with the existing evidence on business cycle correlations. ${ }^{6}$ Bayoumi and Eichengreen (1993) find that growth rates are substantially more correlated among the 8 U.S. regions defined by the BEA than among 11 EU countries. They find that both demand and supply shocks are more correlated in the U.S. and that U.S. regions adjust more quickly to shocks than EU countries do. Wynne and Koo (1997) also find that correlations are substantially higher among U.S. regions than among European countries. They use Baxter and King (1995) filtered data for the 11 Euro zone countries and for the 12 Federal Reserve Districts, although the latter requires some approximations as the Districts do not always follow state borders.

Our results are also generally consistent with the related literature that decomposes the sources of within-country and cross-country fluctuations into common, national, region-specific, and industry-specific components. While few studies make explicit comparisons between within-country and cross-country results, Clark and Shin (1999) find that much of the evidence indicates that national shocks play a much larger role in

\footnotetext{
${ }^{6}$ Many papers focus on a broader range of countries when comparing intranational to international data. We will not discuss those here. See Clark and Shin (1999) for an overview.
} 
fluctuations across countries than regional shocks play in fluctuations within countries. Although much of the cross-country evidence from this literature is based on non-EU nations, such as the G7, estimates in Clark and Shin indicate that the basic pattern in the literature applies to comparisons of U.S. regions to EU nations.

The variance decomposition literature, however, does include some studies that yield contrary results - most recently, Forni and Reichlin (1998). ${ }^{7}$ Forni and Reichlin decompose fluctuations in regions of European countries into local, national, and European components. Similarly, fluctuations in U.S. counties are decomposed into local, state, and U.S. national components. According to their estimates, the percent of the variation attributable to state shocks in the U.S. is similar to the variance share attributable to national shocks in Europe. Apart from the different methodology, size differences make it hard to compare our results to Forni and Reichlin's. In particular, U.S. counties and states are generally much smaller than European regions and countries. Moreover, Forni and Reichlin's conclusion that pre-monetary union Europe is already highly integrated is based on a small set of core countries. For a larger set of nine EU countries they find that, on average, the variance of nation-specific shocks is about the same as the variance of European shocks, while in the U.S. the variance of state shocks is less than half the variance of national shocks.

Some authors have looked at changes over time in correlation patterns. Angeloni and Dedola (1998) find that GDP correlations between Germany and other EU countries were much higher during the period 1993-1997 than during 1986-1992, which they interpret as a tendency towards the fulfillment of optimal currency area conditions. One has to be careful drawing conclusion from this though as these correlations are based on very short 5-year intervals. While the authors do not report standard errors, our own findings indicate that standard errors can become very large over such short periods. A large drop in the correlation with the German business cycle reported by Angeloni and Dedola from 1979-1985 to 1986-1992 appears consistent with the view that sampling variation, rather than increased integration, is driving these changes over short intervals.

Fatás (1997) also examines changes in European correlation patterns over time, using a dataset of annual employment growth rates for regions within Germany, Italy, France, and the UK. Fatás finds that from 1966-1979 to 1979-1992 the average correlation with aggregate EU-12 employment growth has increased by 0.05 , while the average correlation

\footnotetext{
${ }^{7}$ Bayoumi and Prasad (1997) and Viñals and Jimeno (1996) also conclude that EU regions are as integrated as U.S. states. However, Clark and Shin argue the estimates in these studies can be viewed as consistent with the usual finding that EU regions are less integrated.
} 
with the regions's own country growth rate has dropped $0.15 .^{8}$ During the more recent sample the average correlation with the EU-12 aggregate (0.48) is not much lower than the average correlation with a region's own country $(0.57)$.

These findings are not necessarily inconsistent with ours. First, in the absence of border effects one may expect a region's correlation with the EU-12 aggregate to be substantially larger than with the region's own country as a result of the larger size of the EU-12. Without controlling for size it is hard to draw conclusions. Second, Fatás' results are consistent with our finding that cross-country correlations have not changed much. Fatás finds that over the same two sub-periods the correlation between national employment growth rates of the EU-12 countries with the EU-12 aggregate increased only slightly from 0.49 to 0.57 . This change is likely to be statistically insignificant (standard errors are not reported). Our own calculations show that for the same set of countries (except Luxembourg) the average cross-country correlation increased from 0.23 to 0.26 . The standard error on the small 0.03 increase is 0.10 .

\section{What Accounts for the Border Effect?}

In this section we consider some potential explanations for the border effect. Although many different factors may play a role, we focus on four aspects that have received considerable attention in the debate about European Monetary Union: sectoral specialization, trade, monetary policy and fiscal policy. ${ }^{9}$ Because the necessary data on specialization, etc. are not available for European regions, the analysis is restricted to the U.S.-EU dataset.

Limitations in the U.S.-EU data force us to use different regression specifications. In analyzing specialization, we only report regression results based on the second half of the sample because we do not have comprehensive European data for the first half. In analyzing the roles of trade and fiscal and monetary policy, our regressions use data for both halves of the sample, but only data for EU nations - U.S. regions data are not

\footnotetext{
${ }^{8}$ This drop in within-country correlations is concentrated in the UK and Italy. In Germany and France within-country correlations have not changed much, as we report in Table 4.

${ }^{9}$ We do not consider the role of capital and labor mobility. Empirically these factors are hard to measure, while theoretically one does not expect them to explain the border effect. One would expect the higher capital and labor mobility between the Census regions to reinforce the output and employment effect of asymmetric regional shocks, therefore lowering the business cycle correlation across the Census regions.
} 
used in the regressions. In the case of trade, we must drop the U.S. regions because there are no data on merchandise trade between the Census regions. In the case of monetary policy, the common U.S. currency makes the stance of monetary policy identical for all regions, so any indicator of monetary policy across Census regions is equivalent to a border dummy. For consistency, we use the same EU-only approach in the fiscal policy regressions, even though fiscal policy does differ somewhat across Census regions.

\subsection{Production Structure}

Trade barriers and industrial policy are likely to have an effect on production structures, which in turn can affect business cycle synchronization. As noted by Clark (1998), Imbs (1998b), and Krugman (1993), among others, greater similarity in production structures is likely to increase business cycle correlations. Industry-specific shocks will create more comovement among regions with similar production structures than among regions with dissimilar structures. To the extent that regions within a country have more similar production structures than regions in different countries, some of the border effect may be attributable to sectoral specialization.

To measure similarity in industry specialization, we adopt the absolute value index suggested by Krugman (1991). Letting $s_{n j}$ and $s_{n k}$ denote the GDP shares for industry $n$ in regions $j$ and $k$, the similarity of region $j$ 's and region $k$ 's production structures is measured as

$$
\sum_{n=1}^{N}\left|s_{n j}-s_{n k}\right| .
$$

In the regression results discussed below, the GDP shares in (5) are measured as the average of sectoral output shares from 1980 to 1993, the sample over which all necessary industry GDP data are available. Because data for Ireland, Portugal, and Spain are incomplete, these countries are excluded, and only the EU-11 countries are used in the specialization analysis.

Because industry specialization may affect business cycle comovement through a variety of mechanisms, we measure specialization with several different sectoral breakdowns. As detailed in the appendix, we use one broad measure that covers essentially 10 one-digit industries, a narrower measure that covers 8 one-digit non-manufacturing industries and 8 two-digit manufacturing industries, and, in results not reported, a measure based on just 8 two-digit manufacturing industries. If, as suggested by Long and Plosser (1983), among others, business cycles are driven by shocks specific to broad 
industries, the degree of specialization across broad industries will be an important determinant of the degree of regional comovement. On the other hand, to the extent barrier-free trade allows specialization in the production of traded goods, specialization in manufacturing may be important.

Most of the existing evidence on specialization is based only on the manufacturing sector. Krugman (1991) shows that manufacturing is more specialized across 4 large U.S. regions than across the 4 largest European countries. He expresses concern that business cycles may become less synchronized in Europe when the degree of specialization becomes similar to that in the United States. But as pointed out by Peri (1998), the comparison is not valid because Krugman's U.S. data are for 1977, while the EU data are for 1985. As shown in Kim (1995), the U.S. Census regions have gradually become less specialized during the post-war period. Peri (1998), based on the same U.S. regions and European countries as in Krugman (1991), finds that in 1986 the degree of specialization in the U.S. was about the same as that in Europe.

In our data, U.S. Census regions are, by most measures, less specialized than EU nations. For example, as shown in the upper panel of Figure 3, our 10 sector-based specialization index across Census regions is about 0.24 since the mid-1980s, compared to an average of about 0.30 for EU nations. Our narrower 16-sector index produces roughly the same figures. When coverage is limited to 8 two-digit manufacturing industries, specialization is roughly the same in U.S. Census regions and EU nations, consistent with Peri (1998). Figure 3 also confirms the trend towards decreased regional specialization in the U.S. documented in Kim (1995). In Europe the extent of specialization has not changed much since the mid-1970s, a finding also reported by Peri (1998).

Ultimately, industry specialization helps explain cross-region correlations, but can account for only a small part of the border effect. As shown in Table 5, for the U.S.EU dataset industry specialization has strong explanatory power when using annual employment growth data. But its effect is small and insignificant for GDP growth rates. Results for $\mathrm{HP}$-filtered data, omitted in the interest of brevity, are similar. We are not sure what causes the employment-GDP difference. In other results not shown, specialization tends to have more explanatory power across Census regions than across EU nations. ${ }^{10}$ Although including the structure variables does not change the border

\footnotetext{
${ }^{10}$ But when specialization is measured using 8 two-digit manufacturing industries, this result is reversed: specialization has more explanatory power across EU countries than the Census regions. This last result is consistent with findings in the variance decomposition literature, based on 2-digit manufacturing sectors, that industry-specific shocks are a larger source of variation in European countries
} 
effect when using annual GDP growth rates, it lowers it somewhat based on employment growth rates: from 0.40 to 0.36 for the 10 -sector index, to 0.32 for the 16 -sector index, and to 0.39 for the index based on 8 manufacturing sectors. The fact that European countries are more specialized than U.S. regions therefore can account for at most 0.08 of their lower business cycle correlations.

Changes in the extent of specialization are unlikely to account for the decline in the border effect documented in section 3. While the approximately constant degree of specialization in Europe is consistent with the unchanged business cycle correlations across European countries, the decrease in specialization in the U.S. cannot explain the drop in business cycle correlations across U.S. Census regions.

\subsection{Trade}

The absence of data on merchandise trade among U.S. Census regions complicates the analysis of whether a lower level of trade in Europe than in the U.S. accounts for the estimated border effect. We first evaluate the importance of bilateral European trade in regressions involving only European business cycle correlations. In order to determine how much European business cycle correlations would rise if the level of trade were similar to that among the Census regions, we combine the regression results with an approximation of average trade between the Census regions.

In approximating the average level of Census region trade, we rely on two data sources. The first is the U.S. Census Bureau's 1993 Commodity Flow Survey, which provides data on both within-state and cross-state shipments. We aggregate these state data to obtain shipments among Census regions. These figures overstate the extent of trade because all shipments, rather than just shipments from source to final destination, are counted. We therefore scale down the estimates using a measure of overall domestic merchandise trade. Following Helliwell (1997, 1998) and Wei (1996), we approximate overall trade as gross output in mostly goods producing sectors, minus merchandise exports. The data appendix provides additional details.

We consider two different measures of trade. The first, taken from Frankel and Rose (1998), captures the bilateral trade intensity between regions $j$ and $k$ :

$$
T R A D E_{j k}^{1}=\frac{1}{T} \sum_{t} \frac{X_{j k t}+M_{j k t}}{Y_{j t}+Y_{k t}}
$$

than in U.S. regions. See Clark and Shin (1999). 
where $X_{j k t}$ denotes total nominal merchandise exports from region $j$ to $k, M_{j k t}$ represents imports to $j$ from $k$, and $Y_{j t}$ denotes nominal GDP in region $j$. Bilateral merchandise exports and imports data are from the IMF's Direction of Trade Statistics.

Because this first trade variable is size-dependent - likely to be higher for larger regions - we use a second measure of bilateral trade intensity that is not size-dependent. As formalized in Deardorff (1998), bilateral trade between $j$ and $k$, multiplied by world GDP and divided by the product of the GDPs of $j$ and $k$, is equal to one if preferences are homothetic and there are no trade barriers. ${ }^{11}$ More generally it is a function of transport costs and tariff barriers. ${ }^{12}$ Accordingly, we construct a second trade variable:

$$
T R A D E_{j k}^{2}=0.5 \frac{1}{T} \sum_{t} \frac{\left(X_{j k t}+M_{j k t}\right) Y_{t}^{W}}{Y_{j t} * Y_{k t}},
$$

where $Y_{t}^{W}$ is world GDP. Because this second trade measure depends on trade barriers, but not on size, it provides a more accurate picture of the extent of integration among regions. The lower panel of Figure 3 shows a time series of the second trade measure for EU-14 trade. The level of trade among European countries has substantially increased over time. It is about $50 \%$ higher at the end of the sample than at the beginning of the sample, rising from 0.48 in 1960 to 0.73 in $1996 .^{13}$

Three issues arise when including trade variables in European business cycle regressions. First, when adding these trade variables to a regression of correlations on a constant, distance and size, the coefficient on distance becomes small and insignificant. This is exactly what one would expect when the effect of distance on business cycle correlations takes place mostly though its effect on trade. We therefore take distance out of the regressions. Second, Frankel and Rose (1998) argue that trade may be endogenous. In particular, countries whose business cycles are highly correlated are better candidates for an optimum currency area and may therefore adopt a monetary policy leading to more stable bilateral exchange rates. This, in turn, could increase the level of trade. In order to avoid such endogeneity problems we instrument the trade variable. The instruments we use are distance, an adjacency dummy, a dummy variable that is

\footnotetext{
${ }^{11}$ There is only final goods trade in Deardorff's model. Taking into account intermediate and capital goods trade, the number can be expected to be larger than one in the absence of trade barriers.

${ }^{12}$ See also Wei (1996).

${ }^{13}$ The temporary blip in the 1980s is a result of the large dollar appreciation and depreciation during that period, which affected the dollar value of European trade and GDP more than the dollar value of world GDP.
} 
one if two countries' legal systems have the same origin, ${ }^{14}$ and the sum of central bank independence indexes for countries $j$ and $k$ (from Cukierman et.al. (1992)). Finally, we also would like to exploit the fact that trade has increased during the sample, which may have increased business cycle correlations. We therefore estimate regressions for the first and second half of the sample jointly, assuming that the sampling error $v$ in (1) is uncorrelated across the subsamples. The sub-samples are 1961-1979 and 1980-1997.

The results are reported in Table 6 . In order to save space we only report results for two business cycle measures, annual growth rates of employment and GDP. We use natural logarithms of the bilateral trade measures. We report results both with and without instrumenting the trade variables. The last column reports the increase in the average business cycle correlation that is the result of the increase in average trade from the first to the second half of the sample. This is computed by multiplying the coefficient on trade by the change in the average level of trade.

Both trade measures have the expected sign, and are highly significant. In most cases the coefficient on the trade variable when using instrumental variables is somewhat larger than when estimating the coefficients with OLS. The last column shows that the increase in the level of trade from the first to the second half of the sample can be expected to raise business cycle correlations by at most 0.06 . Such a small change is consistent with the finding in Table 4 that European business cycle correlations have remained almost unchanged.

A simple comparison of average U.S. and EU trade levels suggests that the level of trade among regions in the U.S. is substantially higher than among European countries. For European countries the average level of $\operatorname{Trade}_{i j}^{2}$ is 0.67 in 1993 . Using the approximation for U.S. trade described above and in the appendix, we find that the average level of Trade $_{i j}^{2}$ for Census regions is 1.10 in 1993, or $64 \%$ higher than among the EU countries.

In order to determine to what extent the higher level of the second trade measure in the U.S. can contribute to higher business cycle correlations in the U.S., we need to compare the average of $\ln \left(\operatorname{Trade}_{i j}^{2}\right)$ after controlling for distance and size. For Europe we regress $\ln \left(\operatorname{Trade}_{i j}^{2}\right)$ in 1993 on a constant, distance, and size. After substituting the average distance between the Census regions, we find that the average $\ln \left(\operatorname{Trade}_{i j}^{2}\right)$ would be -1.20 in Europe if the average distance were the same as between the Census

\footnotetext{
${ }^{14}$ One might argue that countries with more similar financial systems trade more. La Porta et.al. (1997) establish that the character of a country's financial system is related to the origin of its legal system. The legal families are English, Scandinavian, French and German.
} 
regions. The average among Census regions in 1993 is just -0.08. We therefore would expect $\ln \left(\operatorname{Trade}_{i j}^{2}\right)$ to rise on average by 1.12 in Europe if the size and distance-adjusted level of trade were the same as that among Census Regions. Using the same approach with regards to the first trade measure, we find that $\ln \left(\operatorname{Trade}_{i j}^{1}\right)$ would rise by 1.81 in Europe.

We can evaluate the implications for business cycle correlations of an increase in trade to levels comparable to that in the U.S. by multiplying the increase in trade by the coefficient on the trade variables in the regression. Using the regression results based on instrumental variables and employment growth, we find that European business cycle correlations would rise by 0.24 based on the first trade measure and 0.17 based on the second measure. The maximum border effect we can explain, allowing the coefficients to be two standard errors above the point estimate, is respectively 0.34 and 0.25 . These numbers indicate that most of the border effect in the second half of the sample can be explained through trade, with the more diversified production structure in the U.S. explaining the rest. Table 5 shows that the common border effect is 0.32 after controlling for the 16-sector specialization index. ${ }^{15}$

Consistent with the somewhat smaller border effect based on GDP data, we find that an increase in the level of European trade to U.S. levels would raise GDP growth correlations in Europe by 0.15 for the first trade measure and 0.13 for the second. The maximum border effect we can explain is respectively 0.22 and 0.18 for the two trade measures.

\subsection{Monetary and Fiscal Policies}

An important question in the context of European Monetary Union is the impact of monetary and fiscal policy coordination on business cycle synchronization. It is possible that the single monetary policy within the United States, and the single federal fiscal policy, account for the higher degree of business cycle synchronization among U.S. regions. For example, to the extent that monetary and fiscal policy shocks are themselves a source of business cycles, one would expect that a single policy would lead to higher business cycle synchronization. Common policies may, however, lead to less synchronized business cycles. Skeptics of the single European currency have frequently argued

\footnotetext{
${ }^{15}$ We are not able to add the specialization index to the trade regression because European data are not available for the first half of the sample. It is worth noting though that the trade variables are virtually uncorrelated with the specialization index during the second half of the sample.
} 
that the inability to respond to country-specific shocks can lead to higher business cycle volatility. ${ }^{16}$ The same argument would lead one to expect less synchronized business cycles as policy makers no longer have the flexibility to dampen country-specific shocks.

Ultimately, therefore, the question is an empirical one. In measuring differences in monetary and fiscal policy we are not just interested in differences in exogenous policy innovations. Differences in the response to macroeconomic variables matter as well. We will measure the difference in monetary policy of two regions by the standard deviation of the interest rate differential and the difference in fiscal policy by the standard deviation of the budget deficit differential. It is important, though, to distinguish differences in policies from differences in shocks. Because larger asymmetric shocks can lead to larger interest rate and budget deficit differentials, we use instrumental variables to identify the role of policy differences. The same instruments are used as in the trade regressions discussed above.

We use a quarterly average of overnight money market rates (see the Appendix for details) and subtract inflation over the previous four quarters when computing a measure of expected real interest rates. Since money market rates are not available for many countries during the first half of the sample, we use discount rates for the first half of the sample. Since those change less frequently, we first average the real quarterly interest rate over the year before computing the standard deviation of the annual interest rate differential. The budget deficit data are annual and divided by GDP.

Looking at the raw data for both measures of policy coordination indeed suggests that policy is substantially more coordinated among the Census regions than among the European countries. The average standard deviation of (expected) European real interest rate differentials is 3.31 during the first half of the sample and 3.18 during the second half of the sample. For the U.S. these measures are zero. ${ }^{17}$ We have computed the standard deviation of budget deficit differentials for U.S. regions by computing for each state the budget deficit as the sum of state and local government deficits and an estimate of the federal government's net resource allocation to the state: federal spending in the state plus federal transfers to the state less federal taxes paid by state

\footnotetext{
${ }^{16}$ Martin Feldstein, in a November 1997 Foreign Affairs article, went so far as to raise the prospect of war. For a detailed discussion of difficulties that EMU countries are likely to face in the adjustment to asymmetric shocks, see Obstfeld and Peri (1998).

${ }^{17}$ Here we have assumed zero expected real interest rate differentials for the U.S. states. Money market rates are the same for all states, while Beaudry and van Wincoop (1996) are unable to reject zero expected inflation differentials across four large U.S. regions.
} 
residents (see the Appendix for details). The average over both halves of the sample of the standard deviation of the budget deficit differential is 1.41 for the U.S. regions and 2.86 for European countries.

We again jointly estimate regressions using both halves of the sample for the European data. Table 7 reports results when adding the standard deviation of the real interest rate differential and budget deficit differential to the European regressions. Although not reported, results are similar when using nominal interest rate differentials. Results are reported for different combinations of the monetary policy, fiscal policy and trade variables. Only the second trade variable is included in the regressions, but results are very similar based on the first trade variable. We again report results both based on instrumental variables and OLS.

The overall conclusion that can be reached from Table 7 is that there is little relation between the extent of policy coordination and business cycle correlations. The coefficient on the monetary and fiscal policy variables are almost always insignificantly different from zero. One exception concerns the monetary policy variable when employment growth is used as a business cycle measure, and we use instrumental variables. In that case the monetary policy variable has a negative and significant coefficient of about 0.12. This implies that monetary policy coordination raises business cycle correlations. Although the size of the coefficient is large enough to explain the border effect, the results based on OLS indicate that the role of monetary policy is likely to be much less important than the instrumental variable results suggest. The reason for using instruments in the first place is that one might expect a lower business cycle correlation to increase the standard deviation of interest rate differentials, which would lead to a downward bias in the OLS coefficient. This implies that the correct coefficient on the monetary policy variable is less negative than the -0.03 obtained from the OLS regression, or even positive. In that case monetary policy cannot explain much of the observed border effect. The results based on GDP do yield the expected downward bias when using OLS, although both with IV and OLS the monetary policy variable is never significant. Fiscal policy never enters significantly under either business cycle measure or estimation method.

These results suggest that the border effect is not explained by the higher degree of policy coordination among U.S. regions. This may not be surprising as we already found that the higher level of trade in the U.S., and the somewhat more diversified production structure, can explain almost all of the observed border effect. In Table 7 the coefficient on the trade variable is on average about the same as what we found in Table 6 . The 
only exception is again the case of employment growth rates and instrumental variables.

\section{Conclusion}

We set out in this paper to answer four key questions. First, what is the evidence on the extent of business cycle synchronization among European countries in comparison to regions within the United States? Second, to what extent can we attribute those differences to European national borders? Third, has the role of the border diminished over time? And finally, what accounts for the border effect? The main conclusions can be summarized as follows. We find that business cycle correlations among U.S. regions are significantly higher than among European countries, as much as 0.5 for employment growth rates and 0.4 for GDP growth rates. Second, these differences are mostly related to European national borders. They remain unchanged after controlling for exogenous factors such as distance and size, while more direct evidence on European borders from data of regions within the four largest European countries leads to similar conclusions about the size of the border effect. The European border effect has become somewhat smaller during the second half of the sample (80s and 90s), but this is the result of lower correlations across the Census regions rather than increased synchronization of European business cycles.

The lower level of trade between European countries, and to a lesser extent the higher degree of sectoral specialization, in comparison to U.S. regions, can account for most of the observed border effect during the second half of the sample. We do not find evidence that the higher degree of monetary and fiscal policy coordination among the U.S. regions explains the higher business cycle correlations. Our findings show that the adoption of a single currency in Europe is therefore not likely to soon increase the extent of European business cycle synchronization.

An important topic for future research is to obtain a better understanding of the relationship between trade and business cycles. Bilateral trade is at most a proxy of the intricate trade relationships that exist between regions and countries. One might expect that the business cycle comovements between two regions depend not only on the total level of trade between them, but also on trade with others and the type of goods that are traded. We are likely to achieve a better understanding of the connection between trade and business cycle synchronization in the context of fully developed trade models. 


\section{Data Appendix}

\subsection{U.S.-Europe}

The U.S. Census regions are simple aggregates of states, defined in Clark (1998). Unless otherwise noted, Census region data are derived as simple sums of source state data. For simplicity, just the state sources are detailed below. The European countries we use are Austria, Belgium, Denmark, Finland, France, West Germany, Greece, Ireland, Italy, the Netherlands, Portugal, Spain, Sweden, and the United Kingdom.

Annual employment data for 1961-97 are from the U.S. Bureau of Labor Statistics and the OECD's Annual Labor Force Survey. ${ }^{18}$ Annual, 1963-96 real GDP data for U.S. states and EU-14 countries are from the U.S. Bureau of Economic Analysis (BEA) and the OECD's National Accounts database, respectively. ${ }^{19}$ Real GDP by state is measured using (i) 1963-76 nominal GSP deflated by the U.S. GDP (chain-weight) deflator and (ii) 1977-96 chain-weighted real GSP.

The distance between any two Census regions $j$ and $k$ is a population-weighted average of the geographic distances between the component states (from capital to capital):

$$
D_{j k}=\sum_{l \in j} \sum_{m \in k} \frac{P_{l} P_{m}}{P_{j} P_{k}} D_{l m},
$$

where $D$ and $P$ denote distance and population, respectively. The distance between two EU-14 countries is a population-weighted average of the distances between the NUTS 3 regions comprising each nation. Distances between NUTS 3 regions are a function of latitude and longitude, defined as the coordinates of the center of a box drawn around the region (with minimum excess area). The detailed distance and population data were obtained through Arcview GIS mapping software.

Industry specialization is measured using annual, 1977-96 nominal GSP by state and 1976-1993 gross value added by country, obtained from the BEA and the OECD's National Accounts database. Our first index of specialization covers 10 broad sectors, listed below. Another, more narrow index covers 16 sectors - the eight non-manufacturing industries included in our broad index and the eight manufacturing sectors also listed below. Our final measure of specialization is based on just the 8 manufacturing sectors.

\footnotetext{
${ }^{18}$ For EU nations, 1997 figures are calculated using growth rates from national sources. West German values for 1991-97 are approximated using German growth rates.

${ }^{19}$ National sources were used to estimate 1995 and 1996 values for West Germany.
} 
Broad Industries

Agriculture, forestry, and fishing Transportation, storage, and communications

Mining

Electric, gas, and sanitary

Construction

Wholesale and retail trade, and restaurants and hotels

Manuf.-durable goods

Finance, insurance, real estate, and business and legal services

Manuf.-nondurable goods

Community, personal, and other services and government

Manufacturing Industries

Wood and wood products

Non-metallic mineral products

Basic metals

Fabricated metals and machinery and equipment

Food, beverages, and tobacco Paper and paper products and printing and publishing

Textile, apparel, and leather Chemicals and coal, rubber and plastic products

Annual bilateral merchandise trade data for EU-14 countries over 1960-97 are from the IMF's Direction of Trade Statistics database. ${ }^{20}$ The annual nominal GDP data required in our first and third trade variables are taken from the IFS database, with EU-14 GDP converted to U.S. dollars using exchange rates from the IFS.

The average level of trade among U.S. Census regions is measured by combining two data sources. The U.S. Census Bureau's 1993 Commodity Flow Survey provides data on both within-state and cross-state shipments, covering mostly manufacturing and wholesale trade. ${ }^{21}$ We aggregate the data on shipments between the states to shipments between the Census regions. Because the Commodity Flow Survey-based estimates count all shipments rather than just shipments from source to final destination, we scale down the estimates using an estimate of overall domestic merchandise trade drawn from a second data source. Following Helliwell $(1997,1998)$ and Wei $(1996)$, we approximate total domestic merchandise trade as output in mostly goods producing sectors, minus merchandise exports. Based on discussions with John Helliwell, and with the help of Philip Smith at Statistics Canada, the mostly goods producing sectors are defined as agriculture, mining, manufacturing, construction and electricity, gas and water. ${ }^{22}$ Output data are available in Table 4.1 of the United Nations National Accounts

\footnotetext{
${ }^{20}$ West German trade levels for 1990-97 are adjusted using German growth rates.

${ }^{21}$ There are two important differences between these shipments data and the merchandise trade data. First, unlike the merchandise trade data, the commodity flow data include all shipments, including products that are re-sold rather than produced. Second, the sectoral coverage is not exactly the same. Although the Commodity Flow Survey includes almost all of manufacturing, it excludes agriculture and part of mining, while it includes wholesale trade.

${ }^{22}$ For Canada this definition leads to an approximation of domestic merchandise trade that is almost
} 
Statistics. The total for overall trade in 1993 is 3829 bln. dollars, compared to 5846 bln. dollars in shipments from the Commodity Flow Survey. For each set of Census regions we therefore scale down shipments by $3829 / 5846$.

To compute the monetary policy differential variable, we use the following interest rates for 1981-1997: Austria-Money Market Rate (IFS mnemonic Q12260B); BelgiumCall Money Rate (Q12460B); Denmark-Call Money Rate (Q12860B); Finland-Average Cost of CB Debt (Q17260B); France-Call Money Rate (Q13260B); Germany-Call Money Rate (Q13460B); Greece-Overnight Interbank Rate (OECD Main Economic Indicators); Ireland-Exchequer bills (Q17860C); Italy-Money Market Rate (Q13660B); NetherlandsCall Money Rate (Q13860B); Portugal-Up to 5 Days Interbank Deposit (Q18260B); Spain-Call Money Rate (Q18460B); Sweden-Call Money Rate (Q14460B); U.K. Overnight Interbank Rate (Q11260B). For 1961-1979 we use discount rate data from the IFS. All data are quarterly. We subtract the CPI inflation rate over the previous 4 quarters when computing expected real interest rates. CPI indices are from the IFS.

Budget deficit data as a fraction of GDP are obtained directly from the OECD Economic Outlook. An approximation of the budget deficit for U.S. regions is computed as the aggregate across states of: General Expenditure of State and Local Governments(1)State and Local General Revenues(2)+Transfers from the Federal Government to State and Local Governments(3)+Transfers from the Federal Government to Individuals(4)+Federal Spending by State (5)-Federal Taxes by State(6). (1)-(3) are from Governmental Finances, by the Bureau of the Census, various issues. Data from 1992 to 1996 are from the Bureau of the Census web site. Federal transfers to individuals (4) are computed as in Asdrubali, Sørensen and Yosha (1996). We approximate Federal spending by state (5) as the sum of Federal civil and Federal military production by state, taken from the BEA production structure data. Federal taxes by state (6) are from the BEA as well.

\subsection{European Regional Data}

The NUTS 1 regions we use are listed in Fatás (1997). ${ }^{23}$ Annual employment data for 1970-92 were kindly provided by Antonio Fatás. Real GDP data by region for 1982-96 are obtained by deflating nominal regional GDP with national GDP deflators. Nominal

identical to the total domestic merchandise trade figure obtained through direct estimates by Statistics Canada of interprovincial and intraprovincial merchandise trade flows.

${ }^{23}$ Fatás reduces the total of 11 German NUTS-1 regions to 8 regions in order to avoid using regions that are composed of only large cities. 
GDP data are from Eurostat's REGIO database. Deflators are implicit price indexes from the OECD's Quarterly National Accounts.

Distances between the NUTS 1 regions are measured as population-weighted averages of geographic distances between the NUTS 3 regions within each NUTS 1 region, the same as described for European countries above. 


\section{References}

Angeloni, I. and L. Dedola, 1998. From the ERM to the Euro: a soft transition?, working paper, Bank of Italy.

Asdrubali, P., B.E. Sørensen and O. Yosha, 1996, Channels of Interstate Risksharing: United States 1963-1990, Quarterly Journal of Economics 111, 1081-1110.

Backus, D.K. and P.J. Kehoe, 1992. International evidence on the historical properties of business cycles, American Economic Review, 82, 864-888.

Baxter, Marianne, and Robert G. King, 1995, Measuring business cycles: approximate band-pass filters for economic time series, NBER Working Paper No. 5022.

Bayoumi, T. and B. Eichengreen, 1993. Shocking aspects of European monetary integration. In: F. Torres and F. Giavazzi (Eds.), Adjustment and growth in the European Monetary Union. Cambridge University Press, Cambridge.

Bayoumi, T. and B. Eichengreen, 1996. Operationalizing the theory of optimum currency areas, CEPR Discussion Paper 1484.

Bayoumi, T., and E. Prasad, 1997. Currency unions, economic fluctuations, and adjustment: some new empirical evidence, IMF Staff Papers 44, 36-58.

Beaudry, P. and E. van Wincoop, 1996, The intertemporal elasticity of substitution: an exploration using a U.S. panel of state data, Economica 63, 495-512.

Burnside, C., and M. Eichenbaum, 1996. Small-sample properties of generalized method of moments based Wald tests," Journal of Business and Economic Statistics 14, 294308.

Christiano, L.J. and W.J. den Haan, 1996. Small-Sample Properties of GMM for Business Cycle Analysis, Journal of Business and Economic Statistics 14, 309-27.

Clark, T.E., 1998. Employment fluctuations in US regions and industries: the roles of national, region-specific, and industry-specific shocks, Journal of Labor Economics 16, 202-29.

Clark, T.E. and K. Shin, 1999. The sources of fluctuations within and across countries. In: G. Hess and E. van Wincoop (Eds.), Intranational Macroeconomics, Cambridge University Press, Cambridge, forthcoming.

Cukierman, A., S.B. Webb, and B. Neyapti, 1992. Measuring the independence of central banks and its effects on policy outcomes. World Bank Economic Review 6, 353-98.

Davidson, R.D., and J.G. MacKinnon, 1983. The small-sample performance of the Lagrange Multiplier Test, Economics Letters 12, 269-275. 
Deardorff, A.V., 1998. Determinants of bilateral trade: does gravity work in a neoclassical world? In: Frankel, J.A. (Ed.), The regionalization of the world economy, The University of Chicago Press, Chicago.

Engel, C. and J.H. Rogers, 1996. How Wide is the Border?, American Economic Review $86,1112-1125$.

Engel, C. and J.H. Rogers, 1999. Relative price volatility: what role does the border play?, In: G. Hess and E. van Wincoop (Eds.), Intranational Macroeconomics, Cambridge University Press, Cambridge, forthcoming.

Fatás, A., 1997. EMU: countries or regions? lessons from the EMS experience, European Economic Review 41, 743-751.

Forni, M., and L. Reichlin, 1998. Federal fiscal policies and local economies: Europe and the US, working paper, ECARE, Brussels.

Frankel, J.A., and A.K. Rose, 1998. The endogeneity of the optimum currency area criteria, Economic Journal 108, 1009-25.

Helliwell, J., 1997. National borders, trade and migration, Pacific Economic Review 2, $165-85$.

Helliwell, J., 1998. How much do national borders matter?, Brookings Institution Press, Washington D.C.

Hodrick, R.J. and E.C. Prescott, 1997. Postwar U.S. business cycles: an empirical investigation, Journal of Money, Credit, and Banking 29, 1-16.

Imbs, J., 1998(a). Fluctuations, bilateral trade and the exchange rate regime, manuscript, University of Lausanne.

Imbs, J., 1998(b). Co-Fluctuations, working paper, University of Lausanne.

Kim. S., 1995. Expansion of markets and the geographic distribution of economic activities: the trends in the U.S. regional manufacturing structure, 1860-1987, Quarterly Journal of Economics 60, 881-908.

Krugman, P., 1991. Geography and Trade, MIT Press, Cambridge.

Krugman, P., 1993, Lessons of Massachusetts for EMU, (1993). In: F. Torres and F. Giavazzi (Eds.), Adjustment and growth in the European Monetary Union. Cambridge University Press, Cambridge.

La Porta, R., F. Lopez-de-Silanes, A. Schleifer and R.W. Vishny, 1997. Legal determinants of external finance, Journal of Finance 52, 1131-50.

Long, J. and C. Plosser, 1983. Real business cycles, Journal of Political Economy, 93, 39-69. 
McCallum, J., 1995. National borders matter: Canada-US regional trade patterns, American Economic Review 85, 615-23.

Newey, W.K., and K.D. West, 1987. A simple, positive semi-definite, heteroskedasticity and autocorrelation consistent covariance matrix, Econometrica 55, 703-08.

Obstfeld, M. and G. Peri, 1998. Regional non-adjustment and fiscal policy, Economic Policy 26, 205-260.

Ogaki, Masao, 1993. Generalized method of moments: econometric applications. In: Maddala, R. and Vinod (Eds.), Handbook of Statistics, Vol. 11, North-Holland, Amsterdam.

Peri, G., 1998. Technological growth and specialization, working paper, Bocconi University, Milan.

Puga, D., 1999, The rise and fall of regional inequalities, European Economic Review.

Viñals, J., and J.F. Jimeno, 1996. Monetary union and European unemployment, Discussion Paper No. 1485, Centre for Economic Policy Research.

Wei, S.J., 1996. Intra-national versus international trade, NBER working paper no. 5531.

White, H., 1980. A heteroskedasticity-consistent covariance matrix estimator and direct test for heteroskedasticity,

Econometrica 48, 817-38.

Wolf, H.C., 1999. (Why) Do Borders Matter for Trade? In: G. Hess and E. van Wincoop (Eds.), Intranational Macroeconomics, Cambridge University Press, Cambridge, forthcoming.

Wynne, M. and J. Koo, 1997. Business cycles under monetary union: EU and US business cycles compared, working paper, Federal Reserve Bank of Dallas. 


\begin{tabular}{|c|c|c|c|c|}
\hline Data Set & $\begin{array}{l}\text { business cyle variable } \\
\text { (N=employment) } \\
(\mathrm{Y}=\mathrm{GDP})\end{array}$ & $\begin{array}{c}\text { Average } \\
\text { Within-Country } \\
\text { Correlation }\end{array}$ & $\begin{array}{c}\text { Average } \\
\text { Cross-Country } \\
\text { Correlation }\end{array}$ & $\begin{array}{c}\text { Border } \\
\text { Dummy }\end{array}$ \\
\hline $\begin{array}{l}\text { United States ( } 9 \text { Census regions) } \\
\text { and European Union (14 countries) } \\
36 \text { within-country correlations } \\
\text { (US regions); } 91 \text { cross-country } \\
\text { correlations (EU countries) } \\
N: 1961-1997 \\
Y: 1963-1996\end{array}$ & $\begin{array}{l}\frac{\Delta N}{N} \text {-annual } \\
\frac{\Delta Y}{Y} \text {-annual } \\
N \text {-annual,HP }(10) \\
Y \text {-annual, } \mathrm{HP}(10)\end{array}$ & $\begin{array}{c}0.71 \\
(0.05) \\
0.84 \\
(0.04) \\
0.78 \\
(0.04) \\
0.81 \\
(0.06)\end{array}$ & $\begin{array}{c}0.19 \\
(0.04) \\
0.47 \\
(0.05) \\
0.29 \\
(0.04) \\
0.41 \\
(0.04)\end{array}$ & $\begin{array}{c}0.52 \\
(0.07) \\
0.37 \\
(0.07) \\
0.49 \\
(0.06) \\
0.40 \\
(0.08)\end{array}$ \\
\hline $\begin{array}{l}\text { Nuts } 1 \text { regions within } \\
\text { Germany }(8), \text { France }(8), \\
\text { Italy (11) and UK (11) } \\
166 \text { within-country correlations } \\
537 \text { cross-country correlations } \\
N: 1970-1992 \\
Y: 1982-1996\end{array}$ & $\begin{array}{l}\frac{\Delta N}{N} \text {-annual } \\
\frac{\Delta Y}{Y} \text {-annual } \\
N \text {-annual,HP }(10) \\
Y \text {-annual,HP }(10)\end{array}$ & $\begin{array}{c}0.46 \\
(0.06) \\
0.54 \\
(0.08) \\
0.51 \\
(0.06) \\
0.61 \\
(0.07)\end{array}$ & $\begin{array}{c}0.15 \\
(0.05) \\
0.24 \\
(0.06) \\
0.18 \\
(0.06) \\
0.24 \\
(0.06)\end{array}$ & $\begin{array}{c}0.31 \\
(0.05) \\
0.30 \\
(0.05) \\
0.33 \\
(0.06) \\
0.36 \\
(0.06)\end{array}$ \\
\hline $\begin{array}{l}\text { Nuts } 1 \text { regions within } \\
\text { Germany (8) and France }(8) \\
56 \text { within-country correlations } \\
64 \text { cross-country correlations } \\
N: 1970-1992 \\
Y: 1982-1996\end{array}$ & $\begin{array}{l}\frac{\Delta N}{N} \text {-annual } \\
\frac{\Delta Y}{Y} \text {-annual } \\
N \text {-annual,HP }(10) \\
Y \text {-annual,HP }(10)\end{array}$ & $\begin{array}{c}0.61 \\
(0.08) \\
0.74 \\
(0.06) \\
0.66 \\
(0.05) \\
0.81 \\
(0.05)\end{array}$ & $\begin{array}{c}0.19 \\
(0.08) \\
0.43 \\
(0.12) \\
0.32 \\
(0.10) \\
0.43 \\
(0.10)\end{array}$ & $\begin{array}{c}0.42 \\
(0.09) \\
0.31 \\
(0.11) \\
0.34 \\
(0.07) \\
0.37 \\
(0.11)\end{array}$ \\
\hline
\end{tabular}

Table 1: Cross-Region Business Cycle Correlations

Notes : The table reports the average correlation among regions in the same country and the average correlation among different countries (or regions in different countries). The border dummy is equal to the average within-country correlation less the average cross-country correlation. Standard errors, calculated with GMM methods, are reported in parentheses. The dates in the table refer to the sample periods over which the raw data are available. The notation HP(10) is used to indicate the data have been detrended with the HP filter, with $\lambda=10$. 


\begin{tabular}{|c|c|c|c|c|c|}
\hline Data Set & $\begin{array}{l}\text { Business Cycle } \\
\text { Variable }\end{array}$ & Sample Period & Common Border & $\ln ($ Distance $)$ & Size \\
\hline \multirow[t]{4}{*}{$\begin{array}{l}\text { United States- } \\
\text { European Union }\end{array}$} & $\frac{\Delta N}{N}$-annual & $1962-1997$ & $\begin{array}{c}0.52 \\
(0.08)\end{array}$ & $\begin{array}{l}-0.13 \\
(0.03)\end{array}$ & $\begin{array}{c}0.033 \\
(0.021)\end{array}$ \\
\hline & $\frac{\Delta Y}{Y}$-annual & 1964-1996 & $\begin{array}{c}0.33 \\
(0.06)\end{array}$ & $\begin{array}{l}-0.07 \\
(0.02)\end{array}$ & $\begin{array}{c}0.061 \\
(0.013)\end{array}$ \\
\hline & $N$-annual,HP(10) & 1961-1997 & $\begin{array}{c}0.49 \\
(0.07)\end{array}$ & $\begin{array}{l}-0.10 \\
(0.03)\end{array}$ & $\begin{array}{c}0.027 \\
(0.013)\end{array}$ \\
\hline & $Y$-annual,HP(10) & $1963-1996$ & $\begin{array}{c}0.40 \\
(0.08)\end{array}$ & $\begin{array}{l}-0.09 \\
(0.02)\end{array}$ & $\begin{array}{c}0.032 \\
(0.020)\end{array}$ \\
\hline \multirow[t]{4}{*}{$\begin{array}{l}\text { France- } \\
\text { Germany }\end{array}$} & $\frac{\Delta N}{N}$-annual & 1971-1992 & $\begin{array}{c}0.40 \\
(0.09)\end{array}$ & $\begin{array}{l}-0.04 \\
(0.05)\end{array}$ & $\begin{array}{c}0.015 \\
(0.032)\end{array}$ \\
\hline & $\frac{\Delta Y}{Y}$-annual & $1983-1996$ & $\begin{array}{c}0.23 \\
(0.12)\end{array}$ & $\begin{array}{l}-0.14 \\
(0.03)\end{array}$ & $\begin{array}{c}0.159 \\
(0.052)\end{array}$ \\
\hline & $N$-annual,HP $(10)$ & 1970-1992 & $\begin{array}{c}0.33 \\
(0.09)\end{array}$ & $\begin{array}{l}-0.01 \\
(0.04)\end{array}$ & $\begin{array}{l}-0.023 \\
(0.042)\end{array}$ \\
\hline & $Y$-annual,HP(10) & $1982-1996$ & $\begin{array}{c}0.30 \\
(0.11)\end{array}$ & $\begin{array}{l}-0.13 \\
(0.02)\end{array}$ & $\begin{array}{c}0.149 \\
(0.040)\end{array}$ \\
\hline
\end{tabular}

Table 2: Role of the National Border After Controlling for Size and Distance

Notes : The table reports the results of regressions of the correlation between regions $j$ and $k$ on a constant, a border dummy with value 1 if $j$ and $k$ are within the same country, the log of the distance between the regions, and a measure of the size of the regions. Standard errors are reported in parentheses. The dates in the table period refer to the sample period of estimation. The notation $\mathrm{HP}(10)$ is used to indicate the data have been detrended with the HP filter, with $\lambda=10$. 


\begin{tabular}{||llccccc||}
\hline \hline Data Set & $\begin{array}{l}\text { Business Cycle } \\
\text { Variable }\end{array}$ & $\begin{array}{c}\text { Common } \\
\text { Border } \\
\text { First Half }\end{array}$ & $\begin{array}{c}\text { Common } \\
\text { Border } \\
\text { Second Half }\end{array}$ & ln(Distance) & Size & $\begin{array}{c}\text { change } \\
\text { Border } \\
\text { Coefficient }\end{array}$ \\
\hline United States- \\
European Union & $\frac{\Delta N}{N}$-annual & 0.63 & 0.39 & -0.15 & 0.023 & -0.23 \\
& $\frac{\Delta Y}{Y}$-annual & $0.11)$ & $(0.11)$ & $(0.03)$ & $(0.021)$ & $(0.13)$ \\
& $N$-annual,HP(10) & 0.39 & 0.20 & -0.09 & 0.073 & -0.19 \\
& & $(0.09)$ & $(0.09)$ & $(0.02)$ & $(0.013)$ & $(0.14)$ \\
& $Y$-annual,HP(10) & 0.43 & 0.42 & -0.12 & 0.022 & -0.24 \\
& $(0.11)$ & $(0.11)$ & $(0.02)$ & $(0.020)$ & $(0.16)$ \\
\hline France- & $\Delta N$-annual & 0.40 & 0.34 & -0.01 & 0.030 & -0.05 \\
Germany & $(0.12)$ & $(0.12)$ & $(0.05)$ & $(0.032)$ & $(0.17)$ \\
& $N$-annual,HP(10) & 0.32 & 0.30 & 0.02 & 0.013 & -0.02 \\
& & $(0.12)$ & $(0.12)$ & $(0.04)$ & $(0.043)$ & $(0.16)$ \\
\hline \hline
\end{tabular}

Table 3: Change in the Role of National Borders

Notes : The table reports the results of regressions of the correlation between regions $j$ and $k$ on a constant, a border dummy with value 1 if $j$ and $k$ are within the same country, the log of the distance between the regions, and a measure of the size of the regions. In this case, the correlations are estimated for the first and second halves of the sample. The exact dates of the sample splits are specified in Table 4. The constant and border coefficient are allowed to shift between halves of the sample, while the coefficients on size and distance are restricted to be the same. Standard errors are reported in parentheses, assuming that the sampling error is uncorrelated across both halves of the sample. The notation $\operatorname{HP}(10)$ is used to indicate the data have been detrended with the HP filter, with $\lambda=10$. 


\begin{tabular}{|c|c|c|c|c|c|c|}
\hline Data Set & $\begin{array}{l}\text { Business Cycle } \\
\text { Variable }\end{array}$ & Sample Period & $\begin{array}{c}\text { Average } \\
\text { Within-Country } \\
\text { Correlation }\end{array}$ & Change & $\begin{array}{l}\text { Average } \\
\text { Cross-Country } \\
\text { Correlation }\end{array}$ & Change \\
\hline \multirow[t]{8}{*}{$\begin{array}{l}\text { United States- } \\
\text { European Union }\end{array}$} & $\frac{\Delta N}{N}$-annual & $1962-1979$ & $\begin{array}{c}0.79 \\
(0.07)\end{array}$ & & $\begin{array}{c}0.18 \\
(0.05)\end{array}$ & \\
\hline & $\frac{\Delta N}{N}$-annual & $1980-1997$ & 0.59 & -0.20 & 0.21 & 0.04 \\
\hline & $\frac{\Delta Y}{Y}$-annual & $1965-1980$ & $\begin{array}{c}(0.07) \\
0.84 \\
(0.05)\end{array}$ & $(0.09)$ & $\begin{array}{c}(0.05) \\
0.41 \\
(0.07)\end{array}$ & \\
\hline & $\frac{\Delta Y}{Y}$-annual & 1981-1996 & $\begin{array}{c}0.64 \\
(0.05)\end{array}$ & $\begin{array}{l}-0.20 \\
(0.07)\end{array}$ & $\begin{array}{c}0.40 \\
(0.07)\end{array}$ & $\begin{array}{l}-0.01 \\
(0.10)\end{array}$ \\
\hline & $N$-annual,HP(10) & $1962-1979$ & $\begin{array}{c}0.85 \\
(0.06)\end{array}$ & & $\begin{array}{c}0.21 \\
(0.05)\end{array}$ & \\
\hline & $N$-annual,HP(10) & $1980-1997$ & $\begin{array}{c}0.72 \\
(0.06)\end{array}$ & $\begin{array}{l}-0.13 \\
(0.08)\end{array}$ & $\begin{array}{c}0.31 \\
(0.05)\end{array}$ & $\begin{array}{c}0.10 \\
(0.07)\end{array}$ \\
\hline & $Y$-annual,HP(10) & $1965-1980$ & $\begin{array}{c}0.85 \\
(0.08)\end{array}$ & & $\begin{array}{c}0.40 \\
(0.06)\end{array}$ & \\
\hline & $Y$-annual,HP(10) & 1981-1996 & $\begin{array}{c}0.76 \\
(0.08)\end{array}$ & $\begin{array}{l}-0.09 \\
(0.11)\end{array}$ & $\begin{array}{c}0.42 \\
(0.06)\end{array}$ & $\begin{array}{c}0.03 \\
(0.09)\end{array}$ \\
\hline \multirow[t]{4}{*}{$\begin{array}{l}\text { France- } \\
\text { Germany }\end{array}$} & $\frac{\Delta N}{N}$-annual & $1971-1981$ & $\begin{array}{c}0.67 \\
(0.12)\end{array}$ & & $\begin{array}{c}0.26 \\
(0.11)\end{array}$ & \\
\hline & $\frac{\Delta N}{N}$-annual & 1982-1992 & $\begin{array}{c}0.62 \\
(0.12)\end{array}$ & $\begin{array}{l}-0.05 \\
(0.17)\end{array}$ & $\begin{array}{c}0.26 \\
(0.11)\end{array}$ & $\begin{array}{c}0.00 \\
(0.16)\end{array}$ \\
\hline & $N$-annual,HP $(10)$ & 1971-1981 & $\begin{array}{c}0.70 \\
(0.08)\end{array}$ & & $\begin{array}{c}0.39 \\
(0.14)\end{array}$ & \\
\hline & $N$-annual,HP(10) & 1982-1992 & $\begin{array}{c}0.63 \\
(0.08)\end{array}$ & $\begin{array}{l}-0.07 \\
(0.11)\end{array}$ & $\begin{array}{c}0.34 \\
(0.14)\end{array}$ & $\begin{array}{l}-0.05 \\
(0.20)\end{array}$ \\
\hline
\end{tabular}

Table 4: Change in Correlations

Notes : The table reports average within-country and cross-country correlations in the first and second halves of the sample, along with the change from the first to the second. Standard errors are reported in parentheses, assuming that the sampling error is uncorrelated across both halves of the sample. The dates in the table refer to the sample period of estimation. The notation $\mathrm{HP}(10)$ is used to indicate the data have been detrended with the HP filter, with $\lambda=10$. 


\begin{tabular}{|c|c|c|c|c|c|c|c|}
\hline Data Set & $\begin{array}{l}\text { Business Cycle } \\
\text { Variable }\end{array}$ & $\begin{array}{l}\text { Sample } \\
\text { Period }\end{array}$ & $\begin{array}{l}\text { Common } \\
\text { Border }\end{array}$ & $\begin{array}{c}\text { Log } \\
\text { Dist. }\end{array}$ & Size & $\begin{array}{l}\text { Structure } \\
\text { (Broad) }\end{array}$ & $\begin{array}{l}\text { Structure } \\
\text { (Narrow) }\end{array}$ \\
\hline $\begin{array}{l}\text { United States- } \\
\text { EU(11) }\end{array}$ & $\frac{\Delta N}{N}$-annual & 1980-1997 & $\begin{array}{c}0.40 \\
(0.10) \\
0.36 \\
(0.11) \\
0.32 \\
(0.12)\end{array}$ & $\begin{array}{l}-0.18 \\
(0.04) \\
-0.17 \\
(0.04) \\
-0.16 \\
(0.04)\end{array}$ & $\begin{array}{c}0.057 \\
(0.025) \\
0.060 \\
(0.025) \\
0.061 \\
(0.025)\end{array}$ & $\begin{array}{l}-0.61 \\
(0.26)\end{array}$ & $\begin{array}{l}-0.76 \\
(0.27)\end{array}$ \\
\hline & $\frac{\Delta Y}{Y}$-annual & 1981-1996 & $\begin{array}{c}0.22 \\
(0.10) \\
0.22 \\
(0.10) \\
0.22 \\
(0.10)\end{array}$ & $\begin{array}{l}-0.11 \\
(0.04) \\
-0.11 \\
(0.04) \\
-0.11 \\
(0.04)\end{array}$ & $\begin{array}{c}0.043 \\
(0.026) \\
0.043 \\
(0.026) \\
0.043 \\
(0.026)\end{array}$ & $\begin{array}{l}-0.05 \\
(0.24)\end{array}$ & $\begin{array}{l}-0.04 \\
(0.23)\end{array}$ \\
\hline
\end{tabular}

Table 5: The Border Effect and the Role of Industry Specialization

Notes : The table reports the results of regressions of the correlation between regions $j$ and $k$ on a constant, a border dummy with value 1 if $j$ and $k$ are within the same country, the log of the distance between the regions, a measure of the size of the regions, and the index of industry specialization defined in section 4.1. The index of specialization is calculated using 1979-93 average industry shares in the employment regressions and 1980-93 average shares in the GDP regressions. Results are reported for broad and narrow measures of industry specialization, described in section 4.1. Because data limitations force us to use only data from the second half of the sample and drop Ireland, Portugal, and Spain from the regression, results are also reported for regressions with specialization excluded. Standard errors are reported in parentheses. The dates in the table period refer to the sample period of estimation. 


\begin{tabular}{|c|c|c|c|c|c|}
\hline $\begin{array}{l}\text { Business } \\
\text { Cycle }\end{array}$ & $\begin{array}{c}\text { Estimation } \\
\text { Method }\end{array}$ & Size & $\ln ($ Trade1) & $\ln ($ Trade2) & $\begin{array}{c}\text { Implied } \\
\Delta \text { Correlation } \\
\text { '62-'79 to '80-'97 }\end{array}$ \\
\hline \multirow[t]{4}{*}{$\frac{\Delta N}{N}$-annual } & IV & $\begin{array}{l}-0.010 \\
(0.025)\end{array}$ & $\begin{array}{c}0.131 \\
(0.029)\end{array}$ & & $\begin{array}{c}0.056 \\
(0.012)\end{array}$ \\
\hline & OLS & $\begin{array}{c}0.001 \\
(0.023)\end{array}$ & $\begin{array}{c}0.101 \\
(0.024)\end{array}$ & & $\begin{array}{c}0.043 \\
(0.010)\end{array}$ \\
\hline & IV & $\begin{array}{c}0.056 \\
(0.023)\end{array}$ & & $\begin{array}{c}0.152 \\
(0.035)\end{array}$ & $\begin{array}{c}0.062 \\
0.014)\end{array}$ \\
\hline & OLS & $\begin{array}{c}0.053 \\
(0.023)\end{array}$ & & $\begin{array}{c}0.128 \\
(0.022) \\
\end{array}$ & $\begin{array}{c}0.052 \\
(0.009) \\
\end{array}$ \\
\hline \multirow[t]{4}{*}{$\frac{\Delta Y}{Y}$-annual } & IV & $\begin{array}{c}0.043 \\
(0.013)\end{array}$ & $\begin{array}{c}0.081 \\
(0.019)\end{array}$ & & $\begin{array}{c}0.035 \\
(0.008)\end{array}$ \\
\hline & OLS & $\begin{array}{c}0.040 \\
(0.013)\end{array}$ & $\begin{array}{c}0.092 \\
(0.022)\end{array}$ & & $\begin{array}{c}0.040 \\
(0.009)\end{array}$ \\
\hline & IV & $\begin{array}{c}0.086 \\
(0.017)\end{array}$ & & $\begin{array}{c}0.112 \\
(0.026)\end{array}$ & $\begin{array}{c}0.046 \\
(0.011)\end{array}$ \\
\hline & OLS & $\begin{array}{c}0.083 \\
(0.017)\end{array}$ & & $\begin{array}{c}0.087 \\
(0.023)\end{array}$ & $\begin{array}{c}0.036 \\
(0.010)\end{array}$ \\
\hline
\end{tabular}

Table 6: EU-14 Trade Regressions

Notes : The table reports the results of OLS and instrumental variable regressions of the correlation between nations $j$ and $k$ on a constant, a measure of the size of the nations, and one of the trade indexes defined in section 4.2. The correlations are estimated for the first and second halves of the sample, specified in Table 4. The constant is allowed to shift between halves of the sample, while the coefficients on size and trade are not. Standard errors are reported in parentheses, assuming that sampling error is uncorrelated across both halves of the sample. The instruments are log distance, an adjacency dummy, a dummy variable that is one if two countries' legal systems have the same origin, and the sum of central bank independence indexes for countries $j$ and $k$. The implied change in the average correlation is calculated by multiplying the coefficient on trade by the change in the average level of trade between the first and second halves of the sample. 


\begin{tabular}{|c|c|c|c|c|c|}
\hline $\begin{array}{l}\text { Business } \\
\text { Cycle }\end{array}$ & $\begin{array}{c}\text { Estimation } \\
\text { Method }\end{array}$ & $\sigma_{r-r^{*}}$ & $\sigma_{b d-b d^{*}}$ & $\ln ($ Trade2) & Size \\
\hline \multirow[t]{6}{*}{$\frac{\Delta N}{N}$-annual } & IV & $\begin{array}{c}-0.12 \\
(0.04)\end{array}$ & & $\begin{array}{c}0.03 \\
(0.05)\end{array}$ & $\begin{array}{c}0.020 \\
(0.025)\end{array}$ \\
\hline & OLS & $\begin{array}{l}-0.03 \\
(0.02)\end{array}$ & & $\begin{array}{c}0.11 \\
(0.02)\end{array}$ & $\begin{array}{c}0.046 \\
(0.023)\end{array}$ \\
\hline & IV & & $\begin{array}{c}-0.04 \\
(0.06)\end{array}$ & $\begin{array}{c}0.13 \\
(0.04)\end{array}$ & $\begin{array}{c}0.041 \\
(0.036)\end{array}$ \\
\hline & OLS & & $\begin{array}{l}-0.03 \\
(0.03)\end{array}$ & $\begin{array}{c}0.12 \\
(0.02)\end{array}$ & $\begin{array}{c}0.042 \\
(0.026)\end{array}$ \\
\hline & IV & $\begin{array}{c}-0.12 \\
(0.04)\end{array}$ & $\begin{array}{c}-0.02 \\
(0.06)\end{array}$ & $\begin{array}{c}0.02 \\
(0.05)\end{array}$ & $\begin{array}{c}0.015 \\
(0.036)\end{array}$ \\
\hline & OLS & $\begin{array}{c}-0.03 \\
(0.02)\end{array}$ & $\begin{array}{c}-0.02 \\
(0.03)\end{array}$ & $\begin{array}{c}0.11 \\
(0.02)\end{array}$ & $\begin{array}{c}0.039 \\
(0.025)\end{array}$ \\
\hline \multirow[t]{6}{*}{$\frac{\Delta Y}{Y}$-annual } & IV & $\begin{array}{c}0.02 \\
(0.02)\end{array}$ & & $\begin{array}{c}0.14 \\
(0.04)\end{array}$ & $\begin{array}{c}0.093 \\
(0.018)\end{array}$ \\
\hline & OLS & $\begin{array}{c}-0.01 \\
(0.01)\end{array}$ & & $\begin{array}{c}0.08 \\
(0.02)\end{array}$ & $\begin{array}{c}0.081 \\
(0.017)\end{array}$ \\
\hline & IV & & $\begin{array}{c}0.06 \\
(0.04)\end{array}$ & $\begin{array}{c}0.14 \\
(0.03)\end{array}$ & $\begin{array}{c}0.111 \\
(0.022)\end{array}$ \\
\hline & OLS & & $\begin{array}{c}-0.02 \\
(0.02)\end{array}$ & $\begin{array}{c}0.08 \\
(0.02)\end{array}$ & $\begin{array}{c}0.075 \\
(0.016)\end{array}$ \\
\hline & IV & $\begin{array}{c}0.02 \\
(0.02)\end{array}$ & $\begin{array}{c}0.06 \\
(0.04)\end{array}$ & $\begin{array}{c}0.16 \\
(0.04)\end{array}$ & $\begin{array}{c}0.115 \\
(0.023)\end{array}$ \\
\hline & OLS & $\begin{array}{c}-0.02 \\
(0.02)\end{array}$ & $\begin{array}{c}-0.00 \\
(0.01)\end{array}$ & $\begin{array}{c}0.08 \\
(0.02)\end{array}$ & $\begin{array}{c}0.074 \\
(0.016)\end{array}$ \\
\hline
\end{tabular}

Table 7: EU-14 Regressions: The Role of Monetary and Fiscal Policy

\begin{abstract}
Notes : The table reports the results of OLS and instrumental variable regressions of the correlation between nations $j$ and $k$ on a constant, a measure of the size of the nations, and various combinations of the second trade index defined in section 4.2, the standard deviation of the real interest rate differential between $j$ and $k\left(\sigma_{r-r^{*}}\right)$, and the standard deviation of the budget deficit differential $\left(\sigma_{b d-b d^{*}}\right)$. The correlations are estimated for the first and second halves of the sample, specified in Table 4. The constant is allowed to shift between halves of the sample, while the coefficients on the other variables are not. Standard errors are reported in parentheses, assuming that sampling error is uncorrelated across both halves of the sample. The instruments are log distance, an adjacency dummy, a dummy variable that is one if two countries' legal systems have the same origin, and the sum of central bank independence indexes for countries $j$ and $k$.
\end{abstract}


Figure 1 Employment Growth Correlations: US-Europe
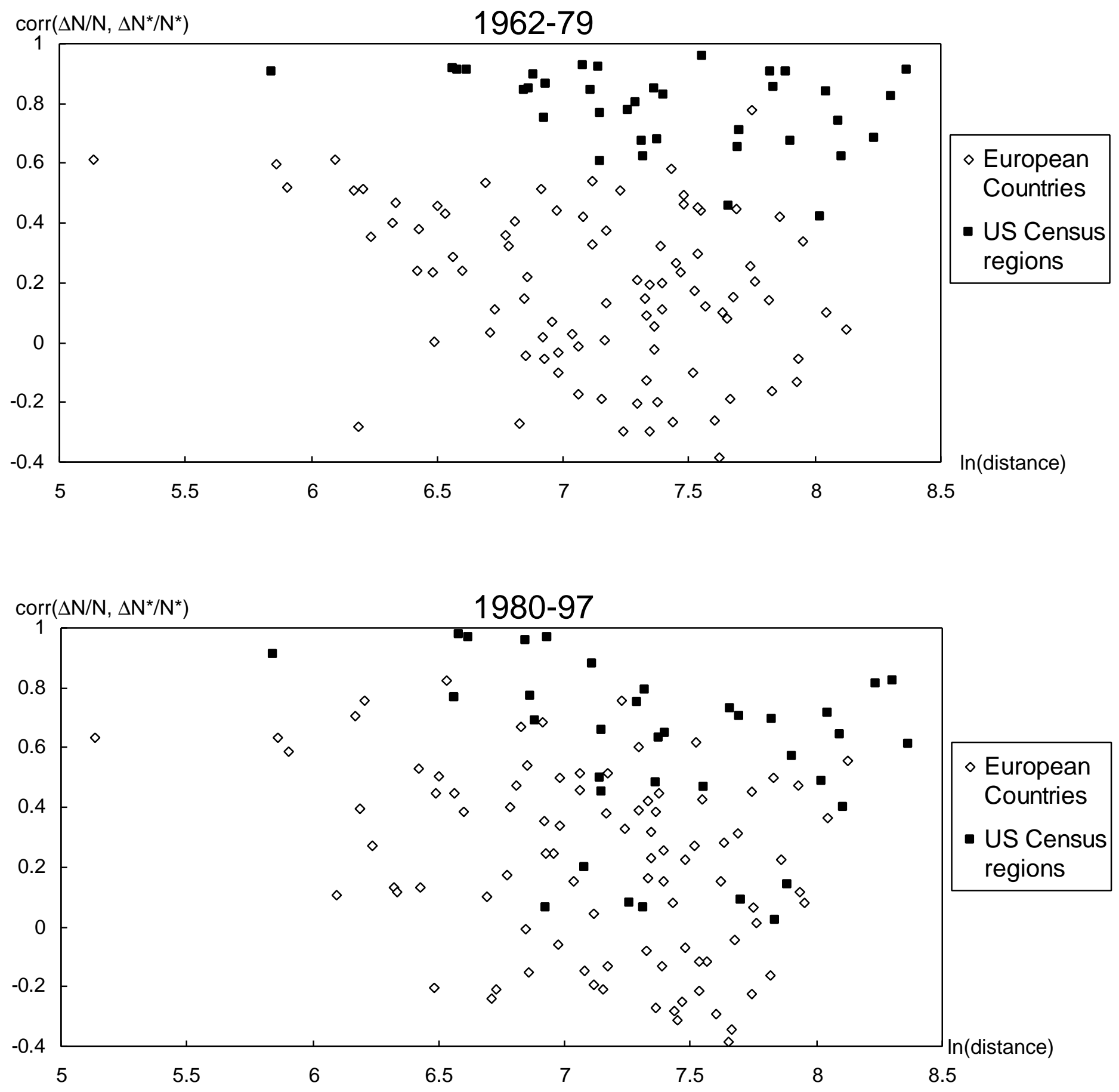
Figure 2 Regional Employment Growth Correlations:

France \& Germany
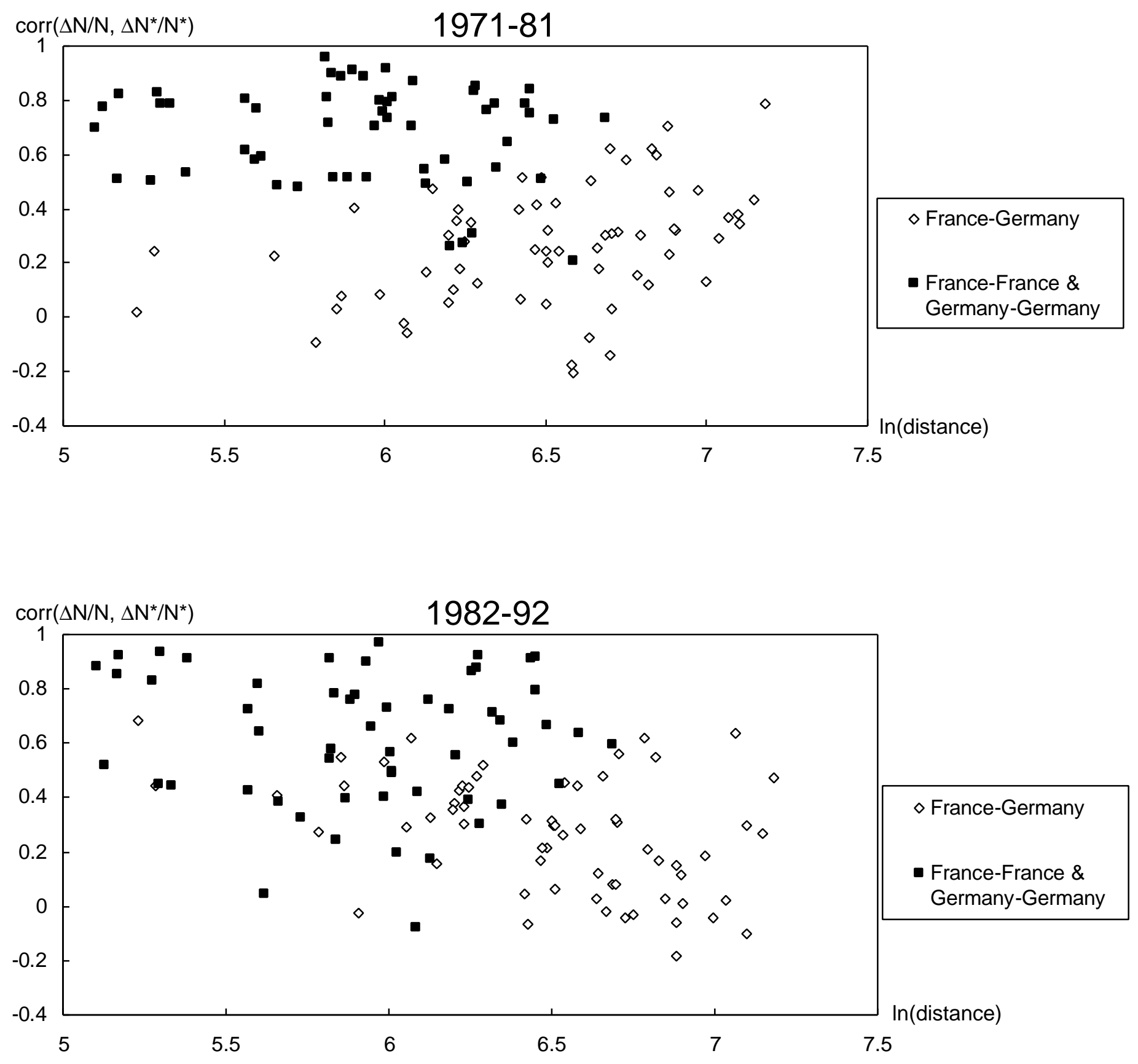


\section{Figure 3 Specialization and Trade Time Series}
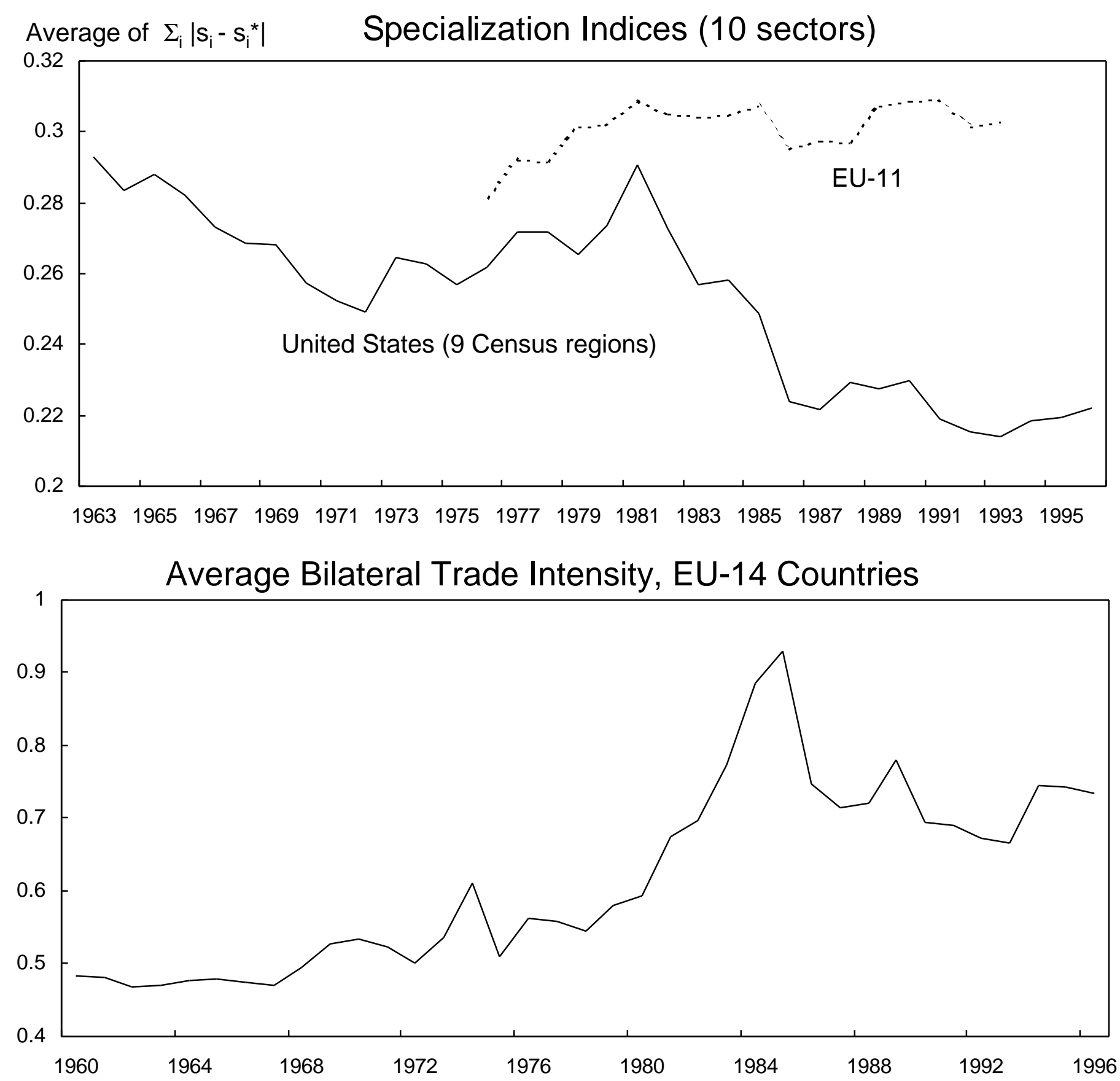

Notes: Specialization: This graph shows an average index of specialization for both the 9 US Census regions and 11 EU countries (all except Ireland, Luxembourg, Portugal and Spain). The index is an average, across all pairs of regions or countries, of the absolute distance between the vectors of sectoral output shares $\left(s_{\mathrm{i}}=\right.$ GDP share of industry $\left.\mathrm{i}\right)$. The results are shown for a set of 10 broad sectors (see data appendix for listing).

Trade: This graph shows the average bilateral trade intensity for trade between EU-14 countries. The bilateral trade intensity between two regions $i$ and $j$ is defined as $0.5\left(X_{i j}+M_{i j}\right)^{*}{ }^{w} /\left(Y_{i}{ }^{*} Y_{j}\right)$, where $X$ and $M$ are exports and imports, $Y W$ is world GDP and $Y_{i}$ and $Y_{j}$ are GDP of regions $i$ and $j$. 